\title{
The Ramifications of Telling Charles Murray to Shut the F*ck Up
}

By Elliot Richardson

In our academic institutions, we are encouraged to debate one another and create productive discourse as a means for solving our problems. But is this an effective tool settling differences if the argument is whether or not you should be considered an equal human being? In cases like these, Iris Marion Young recommends activism as a way to bring attention to ideas that can actually prevent productive discourse. However, is it possible for activism to go "too far" thus shutting down discourse altogether? Applying Young's theory, this paper will explore the roles of both activism and deliberation in the context of a protest at Middlebury College.

Although deliberation and activism often clash with one another, never is this clash more apparent than on a college campus. The function of a college campus is to ensure that each individual student receives a well-rounded education through taking in multiple people's views, and debating them in order to form one's own. Therefore, it seems counterintuitive to not allow specific views to be heard. In 2017, Charles Murray, infamous author of "The Bell Curve" and "Coming Apart: The State of White America 1960-2010”, was invited to speak at Middlebury College by the political science department (Dickinson, 1). Charles Murray, being known for holding racist views, including that people of color are inherently dumber than all white people, was not a popular choice for speaking on Middlebury campus. Therefore, when Murray got up onstage, students promptly turned their backs and began to chant "Who is the enemy? White supremacy," and "Racist, sexist, anti-gay, Charles Murray go away!” (Dickinson, 1). Before this protest, the Middlebury president reminded the students of their school policy that a speaker who comes on campus "has the right to be heard" by the student body. In hopes of promoting productive discourse, professor Allison Stanger, an opponent of Charles Murray, was prepared to debate him after his speech, incorporating questions asked by students and faculty via email and twitter (Dickinson, 2). After 
it became clear that the student body were not going to permit Murray to speak, Stanger took the stage, and told the students that she was prepared to tear down his views in a back-and-forth discussion with him, yet the students continued to chant (Dickinson, 2). They then moved to another location to have a private discussion to be live-streamed to the student body, but were unable to do so since it was impossible to hear over the student's chanting, as well as the pulling of fire alarms in the building (Dickinson, 2-3). After giving up entirely on having any sort of discussion, Stanger and Murray were followed to their car by the protesters, one of which violently pulled Stanger's hair causing her to suffer from whiplash. The protesters then surrounded the car, some even climbing on top of the car, preventing them from leaving the premises (Dickinson, 3).

The situation at Middlebury college is a classic illustration of the clash between discourse and activism. The "deliberative democrats" are here represented by the college as an institution. Young defines the deliberative democrat as: "advocate(ing) processes and action to implement deliberative procedures in actually existing democracy... the deliberative democrat thinks that the best way to limit political domination and the naked imposition of partisan interest and to promote greater social justice through public policy is to foster the creation of sites and processes of deliberation among diverse and disagreeing elements of the polity," (Young, 672).

In the school's eyes, allowing Charles Murray to speak and having one of his opponents publicly debate him was the best course of action for "limiting political domination"; having him be torn down by his opposition in front of the student body of a reputable college may have been more effective in discounting his racist ideas than simply not allowing him to speak. The "deliberative democrat" views activism as an "interest group approach to politics which encourages people to organize groups to promote particular ends through politics and policy by pressuring or cajoling policy makers to serve those interests... they feel no obligation to discuss issues with those whom their interests conflict to come to an agreement they can accept. They simply aim to win the most for their group and engage in power politics 
to do so" (Young, 674). The protesters at Middlebury had no interest in coming to an agreement with the institution, they were simply there to force the school to submit to their unified opinion by overpowering and interrupting their discourse until they "won".

Deliberative democrats view this tactic as "unreasonable", as their definition of reasonable political engagement is willingness to listen to those whom one believes is wrong, demand their reasons, and then give arguments aimed at persuading them to change their minds (Young, 675). This is the very reason why Middlebury had Murray speak at the college in the first place: they wanted their students to hear a point of view that was outrageous in order for them to be better prepared in engaging those with that point of view in debate, thus changing their minds and diminishing the power of said point of view. By simply silencing the view by protest, in the eyes of the institution, Charles Murray has "won" since he now has a view that cannot be debated.

However, this was all seen very differently in the eyes of the students (the activists). Young defines the activist as one who "opposes particular actions or policies of public or private institutions, as well as systems of policies or actions, and wants them changed," (Young, 673). "The activist is often also propelled by anger or frustration at what he judges is the intransigence of people in power in existing institutions, who behave with arrogance and indifference toward the injustices the activist finds they perpetuate or flatly deny them and rationalize their decisions and the institutions they serve as beneficent," (Young, 673). When the political science department hired Charles Murray to speak at the college, the students viewed this behavior as an extension of the injustices already existing within their institution. They strongly believed any tolerance of Murray's views to be indicative of tolerance of racism within the college faculty.

With extremist views, such as Murray's, many believe that any entertainment of these ideas at all decreases the productivity of deliberation; since Charles Murray believes that all people of color are inherently dumber than all white people, than how can one with those beliefs mind be changed by a 
person of color, since they would discount their argument simply because of their race. Young discusses this conflict, saying: "The activist eschews deliberation, especially deliberation with persons wielding political or economic power and official representatives of institutions he believes to perpetuate injustice or harm... He finds laughable the suggestion that he and his comrades should sit down with those whom he criticizes and whose policies he opposes to work out an agreement through reasoned argument they all can accept," (Young, 673). "Powerful officials have no motive to sit down with him, and even if they did agree to deliberate, they would have the power unfairly to steer the course of the discussion... Thus, the activist takes other action that he finds more effective in conveying his criticism and furthering the objectives he believes right: picketing, leafleting, guerilla theater, large and loud street demonstrations, sit-ins, and other forms of direct action, such as boycotts...Often activists make public noise outside where deliberation is supposedly taking place on the inside," (Young, 673). First of all, Charles Murray is particularly known for not being one to change his views, no matter who he debates with, so it is questionable whether or not Stanger debating him would've had any significant educational impact on the students since the discourse would not be "productive". Secondly, Middlebury college has a significant amount of institutional power over its students; they have the power to decide who gets to speak, how that speech should be handled, and even, to some extent, how the students should behave. Although they seem to promote deliberation, they get to control what gets discussed and which arguments are "counted"; for example, a white professor was chosen to debate Murray even though the topic directly harms people of color. Furthermore, Stanger was the one with the power to decide which questions from Facebook and Twitter would be the ones to be asked, so even though it seemed like there would be representation of the opinion of the student body, it was really a distorted version of that voice through the lense of the institution. Before Murray had even come to the college to give his speech, the student body had made it abundantly clear that he would not be welcome in an extensive campus-wide debate, and was even not universally supported by the department sponsoring the event (Dickinson, 1). This illustrates the ultimate 
failing of deliberative democracy; even though the number of students protesting the event greatly outnumbered those who wished to have it, it was still decided upon to have Charles Murray speak. This is because the few who wanted him to speak were within the institution, and thus had more power and political sway in the matter. Therefore, the students had no choice but to protest in order to ensure that their voices were heard.

Another large concern deliberative democrats have with activism is its ability to transform into "extremism". Young discusses extremism as a term which is birthed from a narrow definition of what is "reasonable". By that, she means: " having a sense of a range of alternatives in belief and action and engaging in considered judgment in deciding among them. The reasonable person thus is also able and willing to justify his or her claims and actions to others," (Young, 676). Although the activist's methods are loud and disruptive, they are doing them intentionally for the specific reason of making the public aware of institutional wrongs and persuading the public to join them in pressuring for change in the institutions (Young, 676), and therefore the students were convinced that the actions they were taking to silence Murray were utterly reasonable.

However, the actions taken at Middlebury college were said to have gone beyond disruption and into violence. Many who oppose activism do so because of fear that organizing a group of people for the purpose of shouting a singularly-held belief, who have no interest in engaging in discourse, will ultimately result in violence over those who oppose them, and even (by greatest extension) anarchy. These actions, however, are not received as a valid component of activism, according to Young, as she believes that a true activist will only be violent under the circumstance of self-defense (Young, 674). This remains to be one of activism's greatest weaknesses; it is easy to lose sight of the goal of simply giving voice to an issue of institutional injustice and get caught up in the "thrill" of activist tactics. In the case of Middlebury, the activists crossed the line of what Young considers to be "activism" and turned into an angry mob, which arguably undermined the message the protesters were trying to get across. 
Activism, although it is a critique of deliberative democracy, still relies on it in order to exist; you cannot have critique of political structure without having it in the first place, and has the end-goal of returning to a new, reformed structure (without which, it would just be anarchy). And deliberative democracy, in turn, relies on activism to ensure that these discussions are not perpetuating power structures which effectively silence the voices of certain groups. Although the protest at Middlebury is not a perfect example of what Young considers to be "good activism", it is still important to recognize the reason for the student's protest; the students were opposed to hearing the ideas of Charles Murray because the ideas themselves had the effect of silencing the voices of many others. In other words, the end-goal of the student's activism at Middlebury was to increase deliberation, rather than have it be stifled. This, however, was not the actual outcome of the protest; because Middlebury is a private institution run by people who are chosen by a school board (aka, not a democracy), the school administration saw these actions as a threat to free speech on campus and a violation of their rules. Furthermore, college campuses across the nation refused to hear him speak in fear of another protest, causing many members of the media (including Dr. Dickinson) to categorize the protesters as the "intolerant liberals" and cultivate sympathies for Charles Murray (the opposite effect the students were going for). Therefore, should we continue to prevent Charles Murray, and his supporters, from speaking in order to shut down their racist views? Or is fighting intolerance with intolerance causing more people to defend him? Even Young's theories do not provide enough insight to truly answer this question. 


\section{Sources:}

Dickinson, Matthew. "Murray and Middlebury: What Happened, and What Should Be Done?" Sites DOT Middlebury, Middlebury College, 5 Mar. 2017, sites.middlebury.edu/presidentialpower/2017/03/04/murray-and-middlebury-what-happened-and-what-sh ould-be-done/.

Young, Iris Marion. "Activist Challenges to Deliberative Democracy." Political Theory, 5th ed., vol. 29, Sage Publications, Inc., 2001, pp. 670-690. 